\title{
Local community knowledge and perceptions in the Colombian Caribbean towards Amphibians in urban and rural settings: tools for biological conservation
}

\author{
Danny Vergara-Ríos ${ }^{1}$; Andrés Camilo Montes-Correa ${ }^{2}$; \\ J. Nicolás Urbina-Cardona ${ }^{3}$, Miguel De Luque-Villa ${ }^{3,4}$; Pedro E. Cattan ${ }^{5}$ and \\ Hernan D. Granda-Rodríguez ${ }^{4 *}$
}

\begin{abstract}
Human perceptions vary between rural and urban environments, determining the degree to which people are able to coexist with biodiversity. It is important to identify the sociodemographic factors that determine these local perceptions to adjust amphibian conservation strategies in recognition of the particular conditions of different human communities. In this research, the effect of the urban or rural location where people live and sociodemographic variables in the knowledge and perceptions about amphibians was determined. The data were collected through individual semi-structured surveys of 401 participants. We measured seven response variables through the Likert scale, which ranges from 1 (totally disagree) to 5 (totally agree). For each response variable, a multivariate analysis of variance was performed. Ninety-two percent of people correctly recognized frogs and toads as amphibians, but there was confusion in classifying caecilians and salamanders within this group or including reptiles within amphibians. This confusion was more evident for women from urban locality. Positive perceptions of amphibians varied between urban and rural locality for young adults, people with a high school education level, and people without formal education. Negative beliefs varied between urban and rural locations for women, adolescents, young adults, and professionals. Half of the people accepted information on the conservation of amphibians. Positive perceptions of people about amphibians should be used as a flag to strengthen environmental educational strategies, mainly in urban locations. The results suggest that amphibian conservation plans that aim to inform and educate the public should be focused differently for age groups, genders, and educational level for people in urban and rural locations.
\end{abstract}

Keywords: Local People; Ethnoherpetology; Human Perceptions; Biodiversity Conservation; Local Knowledge; Sierra Nevada de Santa Marta.

1 Facultad de Ciencias Básicas, programa de Biología, Universidad del Magdalena.

2 Grupo de Investigación en Manejo y Conservación de Fauna, Flora y Ecosistemas Estratégicos Neotropicales (MIKU), Universidad del Magdalena, Santa Marta, Colombia.

3 Departamento de Ecología y Territorio, Facultad de Estudios Ambientales y Rurales, Pontificia Universidad Javeriana, Bogotá, Colombia.

4 Grupo de investigación Cundinamarca Agroambiental, Universidad de Cundinamarca, Facultad de Ciencias Agropecuarias, Programa de Ingeniería Ambiental, Facatativá, Colombia.

5 Facultad de Ciencias Veterinarias y Pecuarias, Universidad de Chile, Santiago, Chile.

* Corresponding author $\bowtie$. E-mail address: HDGR (hernangrandar@gmail.com) 


\section{SIGNIFICANCE STATEMENT}

This research explores changes in the perception and knowledge of amphibians by human communities living in rural and urban areas of the Colombian Caribbean. The study region coincides with a biodiversity hotspot with a high degree of amphibian endemism and very high historical deforestation rates. Also, we analyzed the effects of sociodemographic variables (gender, age, and educational level) on perception about amphibians and their interest in learning about strategies for their conservation. The results suggest that amphibian conservation should be approached in a differential manner, not only for people in rural and urban areas, but also in a differential manner for age groups, genders, and educational level for people. In this sense, this study provides perspectives on the implementation of action plans for amphibian conservation based on local social knowledge.

\section{INTRODUCTION}

Local communities are always interested in learning about the environment and the other species with which they coexist (Alves and Souto 2011) Ethnozoology is a discipline that allows us to study and interpret the role played by animals in the culture of different societies (Alves and Souto 2015; Ballejo et al. 2019). Ethnozoological studies provide a broader perspective on the biological phenomenon, contributing to the understanding of how sociocultural aspects shape people's interactions with wildlife (Kimmerer 2002; Nishida and Nordi 2006). However, few ethnoherpetological studies have been carried out in Latin America despite the great importance they represent for the conservation of amphibians and reptiles (Alves and Souto 2011; Alves et al. 2012; Casas Andreu 2004; Gutiérrez-Santillán et al. 2018; Penguilly-Macias et al. 2010).

The perceptions of local human communities towards fauna have a great influence on the conservation of biodiversity, especially in those species in which the perceptions are positive. Perceptions and empathy are generated by aesthetic aspects, customs, folklore, and even evolutionary divergence (Ceríaco 2012; Miralles et al. 2019). However, for those species that are not conspicuous for the common citizen (e.g. due to their cryptic coloration or nocturnal habits), or for which there is a negative perception, it is a challenge to carry out conservation programs, due to reduced interest and limited funds available for a program (Brom et al. 2020).

Amphibians are a highly diverse group in terms of shapes and number of species. Some can be very showy and charismatic, while others are cryptic and warty (Brom et al. 2020; Clarke and Warwick 2001). In general terms, the positive perception of people about amphibians is due to ecosystem functions they fulfill (e.g. in their role as pest controllers; ValenciaAguilar et al. 2013) and the utility they have, highlighting their use as a source of food, fishing lures, in medicine, and as pets, biological laboratory models, and teaching material (Alves et al. 2008; Ceríaco 2012; Cuesta-Ríos and Moreno 2012; Nates-Jimenez and Lindemann-Matthies 2015a; Riós-Orjuela et al. 2020; Tyler et al. 2007). This positive perception has historically been reflected in art, literature, music, and religion and has acquired cultural status within society (Gibbons 2003). Even, amphibians have been considered as deities and some species are used in religious practices (Jensen and Camp 2003). However, in the Catholic religion amphibians have been considered as symbols of the devil (Becker 2000).

Some studies show that negative perceptions about amphibians are influenced by gender, level of education, and the locality where people live (rural or urban), factors that are related to negative experiences or oral tradition (Ceríaco 2012; Pavol and Fančovičová 2012; Tomažic and Šorgo 2017). Multiple beliefs such as that amphibians "inflate until they explode", "spill toxic milk through the skin", "generate warts to the touch" or that "they are useful for witchcraft", originated in this way (Brom et al. 2020; Campos et al. 2013; Gallardo 1994; Henriquez 2012). This is exacerbated by the poor knowledge of the common people about these organisms, since generally people who dislike amphibians ignore their importance in the ecosystem (Pavol and Fančovičová 2012). This type of negative perception generates repulsion, persecution, and sacrifice, as well as the apathy of the general public (Ceríaco 2012) and it reduces the viability of implementing conservation strategies with local communities (Tarrant et al. 2016).

Colombia has the second-highest species richness of amphibians in the world, but it is the first country in number of threatened species (294 species; IUCN, 2020) due to the transformation of ecosystems, pathogens, illegal trafficking, climate change, and other factors (Agudelo-Hernádez et al. 2019; Ministerio de ambiente y desarrollo Sostenible et al. 2021). By 1930, $70 \%$ of Colombians lived in rural locations, but by 2005 there was an abrupt change, so that now $76 \%$ of the population lives in cities (DANE 2018). This shift towards the massive occupation of cities in the country may increase the degree of uprooting of nature, because they lose direct contact with biodiversity (Cleary et al. 2020). In Colombia, there are few studies that relate sociode- 
mographic variables with the perceptions of people towards amphibians. Nates-Jiménez and LindemannMatthies (2015b) report a negative perception of rural and semi-urban people towards amphibians related to a high degree of ignorance. In other human communities, a positive perception about reptiles and a negative one about amphibians was found, which varied depending on the origin and gender of the people (Riós-Orjuela et al. 2020).

The Colombian Caribbean region is characterized by having a high degree of miscegenation, where Afrodescendants, indigenous people, and peasants have been in contact for a long time and shared traditions and mythology about herpetofauna (Legast 1987). For this reason, it is necessary to know the perception of people towards amphibians, to value conservation from a more comprehensive level, and to change negative perceptions so that conservation and environmental educational programs are supported. This study seeks to (I) determine the effects of sociodemographic variables (gender, age and level of studies) on the knowledge about amphibians, as well as on the types and number of amphibians; (II) evaluate the effect of the urban or rural location, gender, age range and educational level on the positive and negative perceptions of people; (III) classify the interviewees based on their positive perceptions, as well as their use and beliefs about amphibians; (IV) understand the degree of interest of urban and rural people in receiving information on how to conserve amphibians based on the socio-demographic variables of the people, as well as their perceptions, uses, and beliefs about amphibians. Negative perceptions of amphibians are expected to be mainly present in urban locations; and these will probably more common among women than men, as well as among adults and older adults than in adolescents and youth. It is also expected that people in rural localities with a higher level of education will be more interested in learning about amphibian conservation strategies.

\section{MATERIAL AND METHODS}

\section{Study area}

This study was carried out in the rural and urban area of the city of Santa Marta $\left(11^{\circ} 14^{\prime} 24.81^{\prime \prime} \mathrm{N}\right.$ and $\left.74^{\circ} 12^{\prime} 43.94^{\prime \prime} \mathrm{W}\right)$ which has an area of $2,393.35$ $\mathrm{km}^{2}$ of which $2,227.13 \mathrm{~km}^{2}$ are rural and $166.22 \mathrm{~km}^{2}$ urban (Figure 1). In physic terms, the environmental heterogeneity of Santa Marta district is a reflection of the life zones produced by the elevation of the Sierra Nevada de Santa Marta (SNSM), an isolated coastal massif that functions as a biogeographic island that rises from sea level to perpetual snow 5775 $\mathrm{m}$ a.s.l (Carbono and Lozano-Contreras 1997). In the low altitudinal band, there is the typical vegetation of the tropical dry forest zonobiome and the humid equatorial zonobiome, which are succeeded by orobiomes of the sub-Andean forest, Andean forest, paramo, super-paramo and nival (snow zone), as the altitude increases (Fundacion Prosierra 1998; Hernández-Camacho and Sanchez 1992).

\section{Survey}

The present social research was conducted from a quantitative perspective using a semi-structured survey with closed questions given the high number of interviewees (Albuquerque et al. 2016; Huntington 2000; Lyra-Neves et al. 2015). The semi-structured survey was conducted in person and was complemented with imaging tests following the methods of Nates-Jiménez and Lindemann-Matthies (2015b, 2015a). This survey sought to deepen the understanding of the interaction between amphibians and people living in the rural and urban area of Santa Marta. Before starting the interview, all participants signed an informed consent form in which they agreed to maintain their anonymity throughout the study.

In March 2017, 200 surveys were carried out in a rural area of Santa Marta. The study participants were randomly selected (94 women and 106 men), aged between 10 years and 87 years. In the urban town, 201 surveys were conducted in April 2017; the participants were randomly selected (98 women and 103 men) with ages ranging from 15 to 72 years. In both locations, people were approached in parks, cemeteries, markets and, in the case of adolescents, in schools during class hours.

Each person was asked if they would be willing to participate in a survey lasting 15 minutes, and 90\% of the people agreed to participate. Each participant was asked to sign a consent form for the survey and in the case of minors that they had the authorization of their parents. The first part of the survey was the characterization of each person based on their age, gender, level of education and locality where they live (rural or urban). To learn about people's perceptions, participants were asked to indicate whether they considered amphibians to be important in nature, as well as positive perceptions (medicinal use, food, pleasant, use as a pet, control of harmful insects, singing behaviors) and negative perceptions (they secrete milky substances, inflate or explode, cause warts in people, carry diseases and are harmful). The responses to each of the questions were expressed on the Likert scale, which ranges from 1: totally disagree; 2: disagree; 3: neither agree / nor disagree; 4: agree; 5: totally agree (Matas 2018). Finally, the respondents were asked if they would be willing to learn more about amphibian conservation. 


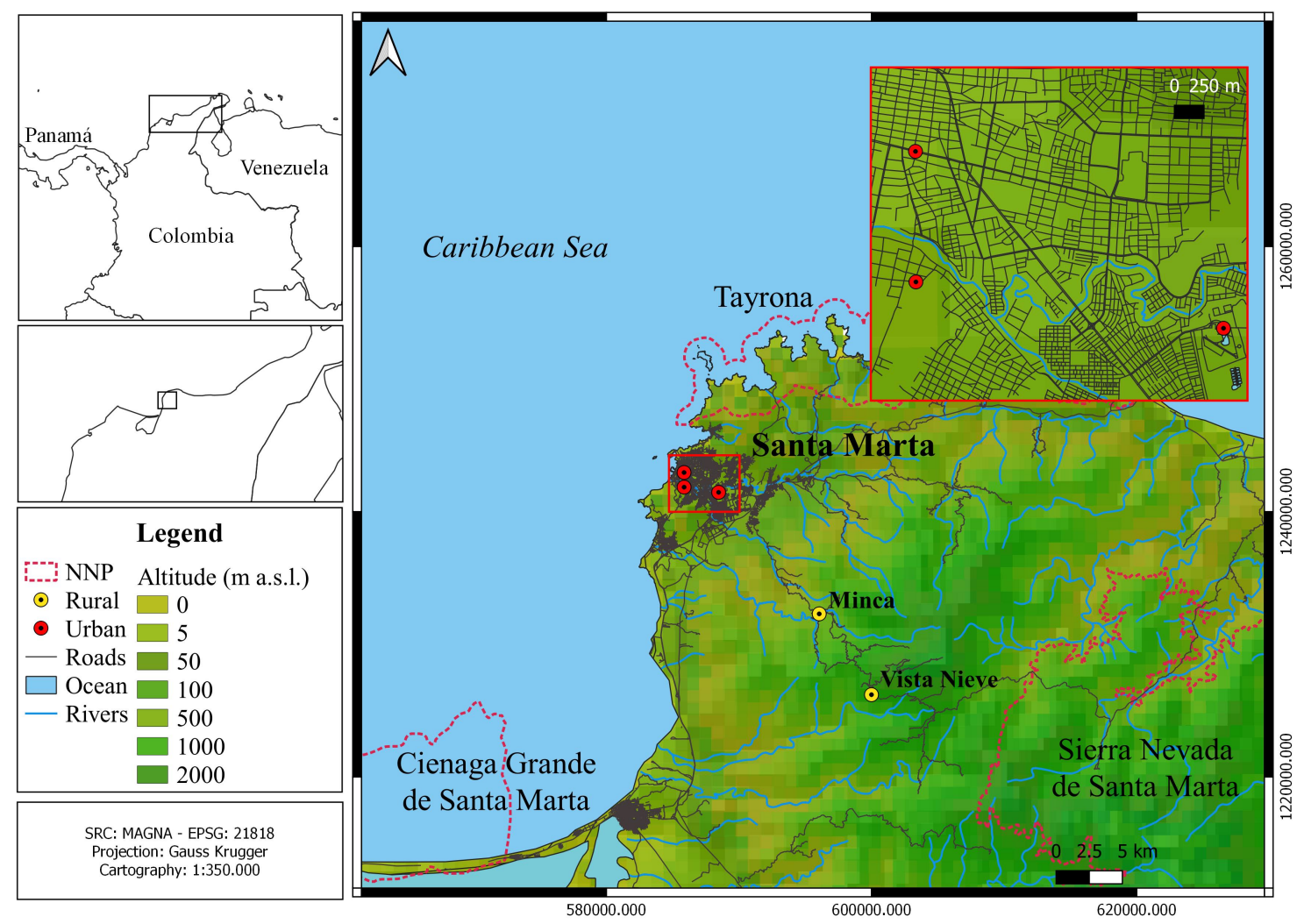

Figure 1. Study area in the transition of tropical dry and sub-Andean forest in Santa Marta, Colombia. Red circles represent, urban locations of Santa Marta: Liceo Samario High School (top left), Agustín Nieto Caballero High School (bottom left) and University of Magdalena (bottom right); Yellow circle represent rural areas: Minca Agro-industrial High School and Sagrado Corazón de Jesús Agroecological High School. The natural protected areas are delimited by red dotted lines.

\section{Picture test}

To assess people's knowledge about amphibians, an image test was given where digital photographs of the following animals were shown: dog, bird, turtle, snake, frog, toad, lizard, salamander and caecilian. After the photos were displayed, the respondents were asked to choose from the images which of these they considered to be amphibians. To investigate the ability of the participants to identify amphibian species in the area, photographs of four native frog species were shown (Acosta-Galvis et al. 2006; Granda-Rodríguez et al. 2020), the periurban species (Montes-Correa et al. 2015) Rhinella horribilis (Wiegmann 1833), Leptodactylus fuscus (Schneider 1799), Boana pugnax (Schmidt 1857) and the endemic Atelopus laetissimus Ruíz-Carranza, Ardila-Robayo \& Hernández-Camacho 1994. In addition, a foreign frog to Colombia Calyptocephalella gayi (Duméril and Bibron 1941); an endemic species from Chile was included as a control for the perception of local species by the participants. The photographs were close-ups in good quality, taken under similar lighting conditions and with the intention of presenting the view from a dorso-lateral aspect. Participants were asked to identify the species by their common name and to indicate whether they were present in the area.

\section{Data analysis}

For the division of ages into groups, four groups were considered: adolescence (12-18 years), young adults (19-30 years), adults (31-60 years) and older adults (61-84 years). Changes in knowledge and perceptions of each of the 401 people interviewed about amphibians were evaluated based on seven response variables: (1) composition of taxonomic groups (salamanders, caecilians, frogs and toads); (2) number of known taxonomic groups; (3) composition of anuran species (four species present in the area and one nonnative: C. gayi, L. fuscus, B. pugnax, A. laetissimus, and $R$. horribilis); (4) number of species of anurans; (5) level of importance of amphibians in nature; (6) positive perceptions about amphibians (medicinal use, food, pleasant, use as a pet, control insects harmful to people, singing); and (7) negative beliefs about amphibians (they secrete milky substances, inflate or 
explode, cause warts in people, carry disease and are harmful). Additionally, we searched for changes on (8) the degree of interest of people to receive information on how to conserve amphibians. For each response variable, a Bray-Curtis matrix previously transformed to square root was generated and a multivariate analysis of variance based on 9,999 permutations (PERMANOVA) with partial sum of squares (type III) and the permutation of residuals under a reduced model was utilized. The experimental design consisted of four fixed factors: locality (levels: urban and rural), gender (levels: male and female), age range (levels: adolescent, young adult, adult and older adult), educational level (levels: none, primary, secondary, technical, professional) and their interactions. To determine the differences between factors, a posterior pairwise comparison was made with the $t$ statistic based on 9,999 permutations.

The eleven perceptions (six positive perceptions with the five negative beliefs) of the people interviewed in urban and rural locations were visualized from the Whittaker association index (WAI). In the heatmap analysis, the WAI ranges from 0 to 4 , showing a pattern of colors (from less warm to warmer) with those surveyed with warmer colors being those who agreed or totally agreed with that perception. The dendrogram for the classification of the people and the one for the classification of the variables were statistically validated using similarity profiles with 9,999 MonteCarlo simulations (SIMPROF routine; Clarke and Warwick 2001).

A Pearson linear correlation was performed between the sociodemographic variables of the people and their knowledge and perception of amphibians to identify collinear variables to exclude from the subsequent analyses. The binary variables were converted to presence-absence (gender, locality), and the level of studies was converted to values from 0 (without formal studies) to 4 (professional with undergraduate studies), for a total of 17 predictive variables that were standardized from their mean and standard deviation. Linear models based on distances (DistLM rutine) were carried out to explain the degree of interest of people to receive information on how to conserve amphibians (response variable ranging from $1=$ totally disagree to $5=$ totally agree) based on the 17 sociodemographic variables of the people and their perceptions about amphibians. The best fitted models were classified using the Akaike information criterion for small samples (AICc). All analyses were carried out using the PRIMER v7 and PERMANOVA + add on programs (Anderson et al. 2008; Clarke and Warwick 2001).

\section{RESULTS}

\section{General aspects}

We interviewed 401 people (192 women and 209 men), of which 200 people lived in rural areas and 201 in urban areas. The level of study was represented by 15 people without formal studies, 136 people who attended primary school, 126 secondary school, 31 did technical studies and 92 were professionals or with undergraduate studies.

\section{Knowledge}

Most people considered frogs and toads as amphibians $(92.26 \%$ and $92 \%$, respectively), but a lower proportion of individuals did so in the case of caecilians and salamanders ( $31.42 \%$ and $61.3 \%$, respectively). However, a large proportion of those surveyed considered reptiles also amphibians (lizards $=42.1 \%$, turtles $=32.16 \%$, and snakes $=33.41 \%$ ). People's knowledge of the taxonomic groups that make up amphibians (salamanders, caecilians, frogs and toads) varied between the urban and rural localities (pseudo$\mathrm{F}=4.94$; p-perm $=0.0001$ ), where the respondents from the first zone recognized reptile groups as amphibians to a greater extent. Variation was also detected among the age ranges (pseudo- $\mathrm{F}=3.254$; $\mathrm{p}$ perm $=0.009$ ) showing less knowledge in people between 19 and 30 years of age. Additionally, there was an effect on the interaction between the locality and gender (pseudo- $\mathrm{F}=2.456 ; \mathrm{p}$-perm $=0.032$ ), although there were only significant differences between women from urban and rural localities (pseudo-t=27.79; pperm $=0.0005$, Add file 1).

Survey results suggested that people are unfamiliar with local amphibian species. Rhinella horribilis was the most frequently recognized species $(53.11 \%)$, followed by B. pugnax (36.15\%). On the other hand, $29.17 \%$ of those surveyed said they had seen the alien species C. gayi, a total of 117 people, of which $84.61 \%$ of these were participants in the urban sector. The knowledge of the people surveyed on the local species was very poor where $35.15 \%$ of the total managed to identify with great difficulty only two species and $21.5 \%$ failed to identify any of the species shown in the questionnaire. The number of species known for amphibians varied between urban and rural locations (pseudo- $\mathrm{F}=1.554$; p-perm $=0.0001$ ) and in the interaction between the location and level of studies (pseudo$\mathrm{F}=0.6 ; \mathrm{p}$-perm=0.042). However, there were only significant differences between people with a technical training level between urban and rural localities (pseudo-t $=2.39 ;$ p-perm $=0.023$ ).

Knowledge of the composition of the five species of anurans present in the area varied between 
the urban and rural localities (pseudo- $\mathrm{F}=2,983 ; \mathrm{p}$ perm $=0.0001)$ and in the interaction between the locality with the age range (pseudo- $\mathrm{F}=0.28$; $\mathrm{p}$ perm $=0.009$ ) and with the educational level (pseudo$\mathrm{F}=0.6 ; \mathrm{p}$-perm $=0.042$ ). Contrast tests showed differences between urban and rural localities for adolescents (pseudo-t $=2.15$; p-perm $=0.0013$ ), young adults (pseudo-t $=2.4 ; \quad \mathrm{p}$-perm $=0.0005$ ) and professionals (pseudo-t $=2.01 ;$ p-perm $=0.004$ ). Knowledge of the richness of the five species of anurans present in the area varied between the urban and rural locality (pseudo- $\mathrm{F}=3.017$; p-perm $=0.0013$ ) and in the interaction between the locality with the gender (pseudo $-\mathrm{F}=1.11$; p-perm $=0.028$ ) and with the age range (pseudo- $\mathrm{F}=0.08$; p-perm $=0.009$ ). Contrast tests showed differences between urban and rural localities for women (pseudo- $\mathrm{t}=2.04 ; \mathrm{p}$-perm $=0.043$ ) and adolescents (pseudo-t $=2.4 ; \mathrm{p}$-perm $=0.0005$ ).

\section{Perceptions}

Ninety-nine percent of people have a positive view of amphibians and their role in nature, but there was a significant difference in the interaction between the urban and rural localities with the age range (pseudo$\mathrm{F}=1.19$; p-perm $=0.025$ ). Contrast tests showed differences between urban and rural localities for young adults (pseudo- $\mathrm{t}=2.23$; p-perm $=0.044$ ) and adults (pseudo-t $=2.26$; p-perm=0.037). Positive perceptions about amphibians varied between urban and rural localities (pseudo-F $=3.537 ;$ p-perm $=0.0001$ ) and in the interaction between the locality with the age range (pseudo- $\mathrm{F}=0.99 ; \mathrm{p}$-perm $=0.04$ ) and with the level of education (pseudo-F=1.002; p-perm=0.044). Contrast tests showed differences between urban and rural localities for young adults (pseudo- $\mathrm{t}=1.72$; $\mathrm{p}$ perm $=0.036)$, people with high school education (pseudo-t $=1.77 ;$ p-perm=0.02) and people without formal studies (pseudo- $\mathrm{t}=2.38$; $\mathrm{p}$-perm $=0.047$ ).

Negative perceptions about amphibians varied between urban and rural localities (pseudo-F $=6.26$; $\mathrm{p}$ perm $=0.002$ ) and in the interaction between the locality with gender (pseudo- $\mathrm{F}=2.57$; $\mathrm{p}$ - perm=0.038), the age range (pseudo- $\mathrm{F}=2.08 ; \mathrm{p}$-perm $=0.037$ ) and with the level of education (pseudo- $\mathrm{F}=1.85$; pperm $=0.037)$. Contrast tests showed differences between urban and rural localities for women (pseudo$\mathrm{t}=1.94 ; \mathrm{p}$-perm $=0.013$ ), adolescents (pseudo- $\mathrm{t}=1.174$; p-perm $=0.033$ ), young adults (pseudo- $\mathrm{F}=1.74$; pperm $=0.043$ ) and professionals with undergraduate studies (pseudo-t $=2.12 ; \mathrm{p}$-perm $=0.006$ ).

The heat map shows that, according to the value of the eleven positive and negative perceptions evaluated, these are grouped into 6 groups as follow: use for food and pets; inflate or explode; they are harmful, cause warts and carry disease; they secrete milky substances; control harmful insects and sing; and they are nice and have medicinal use. Likewise, the people surveyed were grouped, according to their perceptions, into 54 different groups (Figure 2). However, there

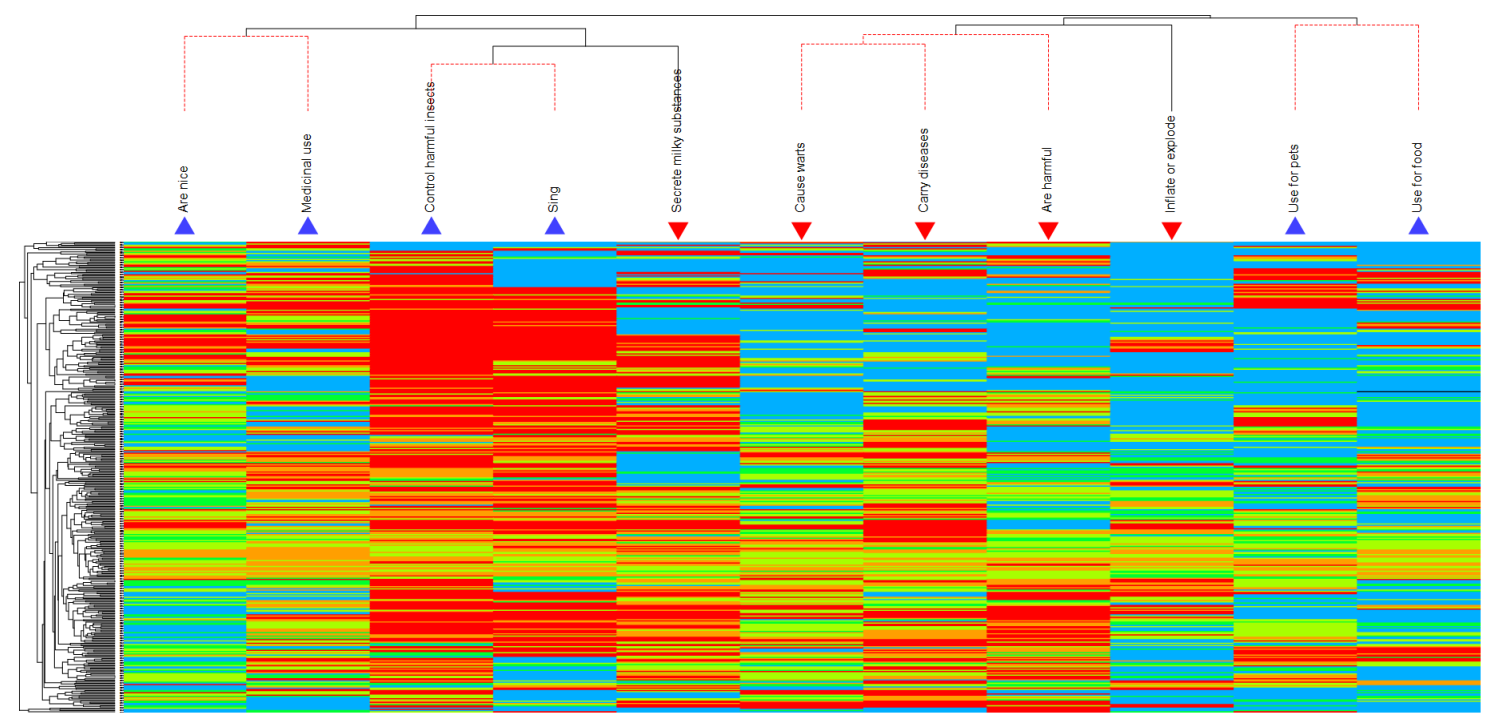

Figure 2. A species heat map of the perceptions of amphibians of the people interviewed in urban and rural locations in the Caribbean region of Colombia. For each person (left tree) their association degree with perception is represented (WAI) with a color palette that goes from red to blue; the hotter tones represent the highest level of association of a person for a specific perception. Positive perceptions are showed by a blue triangle and negative perceptions with a red inverse triangle and were classified into six groups with a mix of positive and negative perceptions. 
was no linear correlation between any of these perceptions, nor between those with sociodemographic factors (age, gender, locality or level of studies). Almost half of the people $(49.2 \%)$ stated that they fully agreed to receive information on amphibian conservation, followed by $26.2 \%$ who agreed and $12.5 \%$ of the people who remained neutral (for details see Add file 2).

\section{Interest in conservation}

The degree of interest of people in receiving information on how to conserve amphibians varied between the urban and rural locality (pseudo- $\mathrm{F}=1.51$; p-perm $=0.0001$ ) and in the interaction between the locality with the age range (pseudo- $\mathrm{F}=0.51 ; \mathrm{p}$ perm $=0.038$ ) and with the level of education (pseudo$\mathrm{F}=0.44 ; \quad$ p-perm $=0.028$ ). Contrast tests showed differences between urban and rural localities for adolescents (pseudo-t $=2.453$; p-perm $=0.018$ ), young adults (pseudo-t $=2.748$; p-perm $=0.007$ ) and professionals with undergraduate studies (pseudo- $\mathrm{t}=2.39$; p-perm $=0.017$; for details see Add file 3 ). This degree of people's interest was explained by different variables depending on the locality. In the city, the two best adjusted models included between two and four variables: that they are considered pleasant, that they can be used as pets, that they control insects and that they secrete milky substances; in the rural areas, the best adjusted model $(\mathrm{F}=8.22 ; \mathrm{p}$-perm $=0.0001$; adjusted $\mathrm{R} 2=22$ ) included eight variables: medicinal use, food use, controlling insects, singing, knowledge of greater number of groups of amphibians (salamanders, caecilians, frogs and toads), which inflate or explode, age and level of studies. Seventy-three percent of adolescents, $90 \%$ of adults and $70.6 \%$ of young adults agreed (sum of responses in categories totally agree and agree) to receive additional information. Regarding the level of studies, all the people without formal training fully agreed to receive additional information on amphibian conservation, while among $67.7 \%$ of the people with technical training, $71.7 \%$ of the professionals, the $73 \%$ of the people with secondary education and $80 \%$ of the people with primary school agreed (sum of responses in categories, totally agree and agree; for details see Add file 4).

\section{DISCUSSION}

This is the first study on the knowledge and perceptions of amphibians by human communities living in the tropical dry forest of the Caribbean. The results of this study points out important sociodemographic factors, such as gender, age and educational level, that influence the interest of people in learning about amphibian conservation strategies, differentiating between urban and rural locations.

\section{Knowledge}

Most of the participants associated frogs and toads with the amphibian group, but very few people managed to classify salamanders and caecilians with this taxonomic group. The foregoing represents a challenge to increase the state of knowledge of the 27 salamanders and 33 caecilians of Colombia (Acosta-Galvis 2021), species that have low abundances, are highly cryptic or live under the ground. Another challenge for future environmental education schemes is that many people classified lizards, turtles and snakes as amphibians, which shows a lack of knowledge of the unique characteristics that amphibians have within the group of vertebrate animals.

Also, people's knowledge about local amphibians was poor, most of the respondents only identified one species, others recognized at least two of those shown in the image tests, and very few managed to exceed that figure, showing a very poor familiarity with native amphibians. The scenario of ignorance could be even worse if it is considered that the five species chosen for the present study (of the 38 species of amphibians in the region) are among the most common in terms of high abundance or probability of detection (Acuña-Vargas 2016; Angarita-M et al. 2015; Granda-Rodríguez et al. 2020, 2012; Roach et al. 2020).

This study showed results similar to those of Nates and Lindemann-Matthies (2015a) and Ríos-Orejuela et al. (2020), where respondents showed difficulties in differentiating amphibians and little familiarity with local species. Statistical tests showed differences between the genera where women from both localities more frequently included reptiles as amphibians (57.85\%), which may be due to the fact that these species are normally associated with unpleasant and frightening appearance (Brom et al. 2020; Campos et al. 2013). Adolescents and young adults also frequently confusing amphibians with reptiles $(63.34 \%$ and $37.15 \%$, respectively), showing that the concept of amphibian is not clear. One reason for this conceptual flaw can be inferred as a limitation of the educational system in the areas of natural sciences, where they are based only on the texts that teachers handle, leaving aside the practical part such as visits to museums, zoos or field trips that enrich students' knowledge about local species. In addition, at this level of education teaching does not take into account or is not clear about the importance of species that are not charismatic, so their biology and ecological aspects are not studied in depth (Torres and Medina 2014). 
Familiarity with local species was very low. The participants showed great difficulty in identifying the species shown in the images and this was more frequent with the inhabitants of the urban locality. This pattern was previously reported by Nates and Lindemann-Matthies (2015a, b), where respondents from sectors closer to the natural areas had more affinity with local species, which is very understandable due to the fact that direct experiences are a rich source of knowledge of wildlife (Tomažič 2011). Works such as that of Brom et al. (2020) in South Africa mention in their results that many of the respondents who had encounters with these species in their childhood showed a broader knowledge about them and a greater retention of this knowledge. The most frequently recognized species for both urban and rural sectors was $R$. horribilis $(36.15 \%)$, because this species is quite common and can be found in a great diversity of ecosystems, including anthropogenic areas (Cortés-Suárez 2017).

We found that $60 \%$ of the women expressed dislike and repulsion for the images shown during the survey, an aspect that exacerbates their fear or disinterest in amphibians (Kellert and Berry 1987). The gender difference in knowledge about the composition of local species in the rural sector may be due to the traditional assignment of roles where from an early age, girls are asked to collaborate with their mothers in housework, while male children are sent with their parents to work in the field. The latter being in closer contact with nature have more knowledge about native species (Nates-Jimenez et al. 2010). A large percentage $(26.61 \%)$ of the urban population indicated that they recognized C. gayi, an Chilean endemic species with no presence in the country. Perhaps this is due to the little contact they have with amphibian populations in the urban area, so its knowledge is built upon foreign biodiversity documentaries seen on television.

\section{Perceptions}

We found differences in the perceptions of people at the level of gender and academic training concerning the premise about the medicinal use of amphibians. Women from both localities and participants in studies at the primary level disagreed, unlike the rest of the participants, especially some respondents from rural areas and people with professional training who gave examples for the use of amphibians in traditional medicine that have been documented both in Latin America and Europe (Alves et al. 2008; Enríquez Vázquez et al. 2006; De La Ossa-Lacayo and De La Ossa 2012; Luiz and Vieira 2014; Teixeira et al. 2020; Vallejo and González 2015). The idea about the nutritional value of amphibians yielded significant differences at the local level, academic training and ages, where participants from the rural sector, adolescents and people without formal education stated that they disagreed with the inclusion of these species in the gastronomic spectrum of people. This is according to Ellen et al.(1976) in Indonesia, where only a select group of some traditional tribes were those that consumed these species. Also, in Pakistan, Ali et al. (2017) found that only $3 \%$ of the surveyed population would use amphibians as food; however, our results showed that people with professional studies and from the urban sector were in agreement with this premise by having a broader gastronomic vision. In the Colombian Amazon, some indigenous communities capture more than 180 species of fauna for their consumption of which eight species are amphibians (Osorno et al. 2014). These results contrast with other studies carried out in China where some 225 species of amphibians are found and $75 \%$ are used as food and for medicinal purposes (Nates-Jimenez and Lindemann-Matthies 2015a; Xie et al. 2007). Likewise, in Nepalese amphibians are often consumed and hunting frogs for food is a fairly common practice in districts such as Gorkha (Shrestha and Shah 2017). These results differ significantly from those obtained in the present study.

Aesthetics played an important role and was a great influence on the sympathy or aversion that people feel towards amphibians. Women from rural localities and adolescents with primary and secondary studies considered amphibians to be unpleasant, and they regularly give value judgments to these species (Campos et al. 2013). In contrast, men from both localities and people with professional training considered amphibians pleasant. These perceptions can be regulated by the knowledge obtained in their education or in their social environment or by direct experiences. Brom et al. (2020) mention that many times the interactions of people with amphibians in their childhood expanded the knowledge of these people about these species and were mostly related to their positive feelings for amphibians. Another positive perception that varied between gender and locality was the use of amphibians as pets, where $80.48 \%$ of the rural population stated that they were against this use, while in the urban population only $40.7 \%$ had the same perception. This may be due to the fact that in rural townships there is a greater predilection for domestic pets, and they do not have much fascination for wild species, an aspect that is more common in the city (Mueses-Cisneros and Ballen 2007). However, the highest percentage of respondents who strongly disagreed that amphibians can be pets were urban women. Among other beliefs that enhance people's positive perceptions of amphibians, we found that the majority of respondents agreed with premises such as 
that amphibians consume harmful mosquitoes, which is to be expected since these species are considered mostly controllers of pests (Peltzer et al. 2005). Only a small percentage of women in the urban sector responded that they did not agree with this belief. On the other hand, the majority of the surveyed population agreed that amphibians can sing. Several participants even made sounds made by frogs and toads that they had heard.

Negative perceptions about fauna are largely influenced by the beliefs and folklore of the region where they give superstitious connotations to animals. In the case of amphibians these are commonly associated with witchcraft and diseases, giving it a negative image in society (Ceríaco 2012). In the present study, differences were found between the public surveyed at the local, gender and school level, where the rural sector, mainly adolescent women distributed between primary and secondary schools were in total agreement with premises such as that amphibians shed milk through their skin, myths that have been transmitted from generation to generation in various human communities (Cuesta-Ríos and Moreno 2012; Gallardo 1994). In contrast, urban young adults with technical and professional academic levels disagreed with these negative myths.

As for whether the respondents considered amphibians harmful, a small percentage distributed among women in the rural sector and some adolescent respondents stated they fully agree with this premise. Likewise, this group considered that amphibians can be carriers of diseases, which can be a confusion with the production of toxins by some species (Kahn et al. 2015). However, people's perceptions of amphibians did not have negative values as broad as those exposed in work published by Prokop and Fancovicová (2012) in Slovakia, where respondents (mainly owners of farms and ponds in the rural sector) claim to feel a strong hatred and repulsion towards amphibians to the point of responding that they felt like killing them. It is possible that the negative results of the present study are less radical due to the poor knowledge of people about amphibians, which may lead to little interest in these species.

\section{Interest in conservation}

Colombia is the country with the second highest number of amphibian species in the world with 849 species, but one third of its species are threatened (Acosta-Galvis 2019, UICN, 2020). The National Program for the Conservation of Amphibians in Colombia and its Action Plan prioritizes a strategic line in education, communication and community participation (Ministerio de ambiente y desarrollo Sostenible et al. 2021). Specifically, in the Caribbean region, this program warns about the impact of illegal amphibian trafficking and the poor appreciation of the importance of amphibians and their ecosystem services by local communities. This is why this policy document highlights the importance of strengthening environmental education and outreach for the apprehension of local and scientific knowledge in order to generate community agreements for amphibian conservation (Ministerio de ambiente y desarrollo Sostenible et al. 2021). However, so far, most amphibian conservation strategies are focused on autoecological evidence without taking into account ethnozoological studies to generate conservation measures that engages local communities in a participatory process (Alves and Souto 2011; Castillo and Ladio 2019).

We understand perception as a constructive process where people organize the stimuli received by the senses to form a conscious or unconscious impression of things in the environment (Merleau-Ponty 1985). In this sense, this interpretation is of great importance in the field of amphibian conservation since people's efforts to conserve species will depend on how they are perceived. According to Castillo and Ladio (2019) fognitive salience and cultural value play an important role in local knowledge of wildlife species; furthermore, they mention that research on cognition, and on how people perceive nature, can give us an idea of the degree of interest in adopting specific conservation actions. Understanding the degree of interest of urban and rural people in receiving information on how to conserve amphibians is one of the objectives of this study. Most of the participants had a positive response to being linked to amphibian conservation programs, in urban areas people interested in conserving amphibians consider them pleasant and useful (for controlling insects or serving as pets). In the rural area, the interested people had a greater knowledge on amphibians, they recognized other uses (medicinal and food), and they liked their song because it has direct interaction with them. This interest in rural people was greater in adolescents, adults and young adults.

It was also found that people with a low level of education in rural areas had a greater interest in learning more. Perhaps the people who live in rural areas, by coexisting in the habitat of amphibians due to their direct relationship with amphibians, have generated greater interest because they are able to hear their songs in the reproductive season and they know about other ecological attributes, unlike people who live in the city where they do not interact with amphibians. Nates-Jiménez and Lindemann-Matthies (2015a) mention that households in rural and remote regions were more dependent on natural resources and more connected to the local environment than households in more urban regions, especially when they 
had low income and have a higher direct relationship with frogs and greater knowledge about them. Several studies have determined that direct experience with fauna increases knowledge and interest in conserving it (Ceríaco 2012). For example, Brom et al. (2020) report that there is a relationship between knowledge and taste for amphibians; and in addition, the positive experiences of people increase their environmental behavior.

All the perceptions of people must be considered, regardless of their origin or veracity. One of the goals of amphibian conservation is to inform and educate the public about the importance of amphibians in ecosystems, and the support of people could make conservation much more successful (Zippel et al. 2011). For example, the few participants who were able to identify the endemic amphibian A. laetissimus gave valuable information about its habitat, commenting that they had seen it in the daytime and in a stream in the region. The participatory inventories and the knowledge of the people who live with the species day by day is very important, since they are species that were believed to be extinct and have been re-registered in areas where they had not been studied, such as the harlequin frog Atelopus lozanoi Osorno-Muñoz, Ardila-Robayo \& RuizCarranza, 2001 which is only known from the original description.

In the rural area of Santa Marta there is a high diversity of amphibians, some of them endemic, such as the monotypic Geobatrachus walkeri Ruthven, 1915 and several Atelopus with good populations status (Granda-Rodríguez et al. 2012, 2020). This region have high potential for ecotourism. Especially an economic strategy including herpetology for tourists could improve the income of families in the Sierra Nevada de Santa Marta (Barrio-Amorós and Manrique 2007). However, the local inhabitants have great ignorance about these species, and this could hinder conservation programs and deteriorate the area due to unsustainable ecotourism (example soil compaction, erosion and habitat alteration), since the area does not have strong environmental institutions to protect the environment (Noriega et al. 2020), which makes environmental education a fundamental component in wildlife conservation planning. It is necessary to have an informed public about the problems and knowledge of the local amphibian species to lead towards more positive perceptions of the local communities towards amphibians. As decision makers have more knowledge and positive perceptions about amphibians, there will be a greater willingness to conserve these species (Lindemann-Matthies 2002). The 21st century is considered the century of extinctions, as some have argued, people will only understand the importance of species if they know them and if they have developed an experiential relationship that mediates significant learning, that is, people will not notice the absence of a species of which they have no knowledge; or they will not be worried about species' extinctions, which raises much concern due to the poor knowledge that local actors have about amphibians and how some negative attitudes reduce the conservation interest for these species (Rudd 2011; Selinske et al. 2020).

\section{CONCLUSION}

This is the first study on amphibian' ethnobiology conducted in the Colombian Caribbean region, where $70 \%$ of the research on amphibians are focused on species abundance, distributions, and checklists (Aldana-Domínguez et al. 2017). Understanding people's perceptions and attitudes on non-charismatic species of fauna will refine and focalize conservation and management efforts, especially in megadiverse countries like Colombia. In this study, people's knowledge of amphibians reflected the little interest that urban people had on native biodiversity. Aesthetics was the main factor affecting the perception of amphibians, with comments about how disgusting are those organisms for people even from a picture. This type of comment occurred mainly in the urban sector, generating great concern about the conservation interest on amphibians in the face of the current extinction crisis. Experiential or direct experience is crucial to consolidating the positive perceptions of people about amphibians, and this highlights the importance of zoos and participatory sampling in meaningful learning. Every amphibian conservation project must have a component that facilitates knowing the perceptions and attitudes of local actors and decision-makers to ensure the persistence of amphibian populations in transformed landscapes.

\section{ACKNOWLEDGEMENT}

The authors thank the agro-industrial district educational institution of Minca, the Agroecological I.E.D Sagrado Corazón de Jesús in Vista Nieve, I.E.D Liceo Samario and I.E.D Agustín Nieto Caballero in Santa Marta for the permits granted and for the logistics provided at the time of the surveys. Patricio Hernaez, Lina Saavedra, Claudia Cerda, Pavol Prokop, Cesar Barrios, and Willinton Barranco made helpful comments on earlier versions of this manuscript. We also thank Adolfo del Portillo, María Alejandra Castillo, Aura Parra, Luisa Fernanda Villalba and Eduardo Barros for field help. Special mention to Juan David Jiménez Bolaño for their dedication to perform the Figure 1. 
Vergara-Rios et al. 2021. Local community knowledge and perceptions in the Colombian Caribbean towards Amphibians in urban and rural settings: tools for biological conservation

Ethnobio Conserv 10:24

\section{DATA AVAILABILITY}

Survey format and raw data at "Data depositing", Mendeley Data, V1, doi: 10.17632/x5txjrvj7b.1

\section{CONFLICT OF INTEREST}

The authors declare that they have no competing interests.

\section{CONTRIBUTION STATEMENT}

PEC and HGR formulated the study and created the survey; MDV, HGR, AMC and DVR conducted the surveys; NUC, HGR, AMC designed and conducted the analyses; MDV, HGR, AMC, DVR; PEC and NUC wrote the manuscript.

\section{REFERENCES}

Acosta-Galvis AR (2021) Lista de los Anfibios de Colombia. http://www.batrachia.com.

Acosta-Galvis AR, Huertas-Salgado C, Rada M (2006) Aproximación al conocimiento de los anfibios en una localidad del Magdalena medio (Departamento de Caldas, Colombia). Revista de la Academia Colombiana de Ciencias Exactas, Físicas y Naturales 30:291-303.

Acuña-Vargas JC (2016) Anfibios y Reptiles asociados a cinco coberturas de la tierra, municipio de Dibulla, La Guajira, Colombia. Acta Zoológica Mexicana 32:133-146.

Agudelo-Hernádez WJ, Urbina-Cardona JN, Armenteras-Pascual D (2019) Critical shifts on spatial traits and the risk of extinction of Andean anurans: an assessment of the combined effects of climate and land-use change in Colombia. Perspectives in Ecology and Conservation 17:206-219.

Albuquerque UP, Cunha LVFC, Lucena RFP, Alves RRN (2016) Methods and Techniques in Ethnobiology and Ethnoecology. Springer, New York.

Aldana-Domínguez J, Montes C, Martínez M, Medina N, Hahn J, Duque M (2017) Biodiversity and Ecosystem Services Knowledge in the Colombian Caribbean: Progress and Challenges. Tropical Conservation Science 10: 1940082917714229.

Ali W, Javid A, Hussain A, Bukhari SM (2017) Public attitude towards amphibian and reptiles in district Kasur, Punjab, Pakistan. Punjab University Journal of Zoology 32:173-178.

Alves RRDN, Da Silva Vieira WL, Santana-Gomes G (2008) Reptiles used in traditional folk medicine: Conservation implications. Biodiversity and Conservation 17:2037-2049.

Alves RRN, Souto WMS (2011) Ethnozoology in Brazil: Current status and perspectives. Journal of Ethnobiology and Ethnomedicine 7:22

Alves RRN, Souto WMS (2015) Ethnozoology: A brief introduction. Ethnobiology and Conservation 4. doi: 10.15451/ec2015-1-4.1-1-13

Alves RRN, Vieira KS, Santana GG, Vieira WLS, Almeida WO, Souto WMS, Montenegro PFGP, Pezzuti JCB (2012) A review on human attitudes towards reptiles in Brazil. Environmental Monitoring and Assessment 184:6877-6901.

Anderson MJ, Gorley RN, Clarke KR (2008) PERMANOVA + for PRIMER: Guide to software and statistical methods. Primer-e, Plymouth, UK.

Angarita-M O, Montes-Correa AC, Renjifo JM (2015) Amphibians and reptiles of an agroforestry system in the Colombian Caribbean. Amphibian 8$\}$ Reptile Conservation 8:19-38.

Ballejo, F, Graña Grilli, M, \& Lambertucci, SA (2019) A long and troublesome journey: People's perceptions and attitudes along the migratory path of a scavenger bird. Ethnobiology and Conservation 8 doi: ec2019-10-8.13-1-13.

Barrio-Amorós CL, Manrique R (2007) Observations of Natural History of the green Anaconda A (Eunectes murinus Linnaeus, 1758) in the Venezuelan Llanos. An ecotoruristic perspective. Fundación Andígena 15:34.

Becker U (2000) The Continuum Encyclopaedia of Symbols. The Continuum International Publishing, New York.

Brom P, Anderson P, Channing A, Underhill LG (2020) The role of cultural norms in shaping attitudes towards amphibians in Cape Town, South Africa. PLoS ONE 15:1-18.

Campos CM, Nates-Jimenez J, Lindemann-Matthies P (2013) Percepción y conocimiento de la biodiversidad por estudiantes urbanos y rurales de las tierras áridas del centro-oeste de Argentina. Ecologia Austral 23:174-183.

Carbono E, Lozano-Contreras G (1997) Endemismos y otras singularidades de la Sierra Nevada de Santa Marta, Colombia. Posibles causas de 
Vergara-Rios et al. 2021. Local community knowledge and perceptions in the Colombian Caribbean towards Amphibians in urban and rural settings: tools for biological conservation

Ethnobio Conserv 10:24

origen y necesidad de conservarlosNo Title. Revista de la Academia colombiana de Ciencias Exactas, Físicas y Naturales 21:409-419.

Casas Andreu G (2004) Nuevas interpretaciones y adiciones a los anfibios y reptiles en la obra del naturalista Francisco Hernández (1517-1584). Ciencia Ergo Sum 11:308-312.

Castillo L, Ladio A (2019) Zootherapy and rural livestock farmers in semiarid Patagonia: the transfer of animal aptitudes for health. Ethnobiology and Conservation 8:1-23. doi: 10.15451/ec2019-01-8.02-1-24

Ceríaco LMP (2012) Human attitudes towards herpetofauna: The influence of folklore and negative values on the conservation of amphibians and reptiles in Portugal. Journal of Ethnobiology and Ethnomedicine 8:1-13.

Clarke K, Warwick R (2001) Change in marine communities: an approach to statistical analysis and interpretation. 2nd edition. Primer-E, Plymouth, United Kingdom.

Cleary A, Fielding KS, Murray Z, Roiko A (2020) Predictors of Nature Connection Among Urban Residents: Assessing the Role of Childhood and Adult Nature Experiences. Environment and Behavior 52:579-610.

Cortés-Suárez JE (2017) Uso de microhábitat por parte del sapo gigante Rhinella horribilis en pastizales en el municipio de Villa de Leyva, Boyacá, Colombia. Revista Biodiversidad Neotropical 7:253-257.

Cuesta-Ríos EY, Moreno LER (2012) Importancia etnozoológica de herpetos en bosques de la selva pluvial central del Chocó. Bioetnia 9:244-56.

DANE (2018) Resultado censo nacional de población y vivienda 2018. Censo-2018.

Duméril AMC, Bibron G (1941) Erpétologie Genérale ou Histoire Naturelle Complète des Reptiles. Paris: Librarie Enclyclopedique de Roret 8.

Ellen RF, Stimson AF, Menzies J (1976) Structure and inconsistency in Nuaulu categories for amphibians. Journal d'agriculture tropicale et de botanique appliquée 23:125-138.

Enríquez Vázquez P, Mariaca Méndez R, Retana Guiascón OG, Naranjo Piñera EJ (2006) Uso medicinal de la fauna silvestre en los Altos de Chiapas, México. Interciencia 31:491-499.

Fundacion Prosierra (1998) Evaluación Ecológica Rápida de la Sierra Nevada de Santa Marta.
Definición de Áreas Críticas para la Conservación de la Sierra Nevada de Santa Marta, Colombia. Ministerio del Medio Ambiente, UAESPPNN The Nature Conservacy -USAID- Embajada de Japón, Santa Marta.

Gallardo JM (1994) Anfibios y Reptiles. Relatos y Leyendas, Etimologías, Usos y Abusos. Librería Agropecuaria, Buenos aires.

Gibbons JW (2003) Societal values and attitudes: their history and sociological influences on amphibian conservation problems. In: Semlistch R. (ed) Amphibian Conservation. Smithsonian Institution, Washington, DC, pp. 324.

Granda-Rodríguez HD, Del Portillo-Mozo A, Renjifo J, Bolaños F (2012) ¿Están declinando todos los Atelopus de alta montaña? el caso de las ranas arlequín de la Sierra Nevada de Santa Marta, Colombia. Herpetotropicos 7:21-30.

Granda-Rodríguez HD, Montes-Correa AC, JiménezBolaño JD, Alaniz AJ, Cattan PE, Hernáez P (2020) Insights into the natural history of the endemic Harlequin Toad, Atelopus laetissimus RuizCarranza, Ardila-Robayo, and HernandezCamacho, 1994 (Anura: Bufonidae), in the Sierra Nevada de Santa Marta, Colombia. Amphibian and Reptile Conservation 14:29-42.

Gutiérrez-Santillán TV, Albuquerque UP, ValenzuelaGalván D, Reyes-Zepeda F, Vázquez LB, Mora-Olivo A, Arellano-Méndez LU (2018) Trends on mexican ethnozoological research, vertebrates case: a systematic review. Ethnobiology and Conservation 9:1-39. doi: 10.15451/ec2020-01-8.01-1-39

Henriquez V (2012) Mitos y leyendas sobre los anfibios y reptiles de El Salvador. Bioma 1:25-27.

Hernández-Camacho JI, Sanchez H (1992) Biomas terrestres de Colombia. In: Halffter GI (ed) La Diversidad Biológica de Iberoamérica. Acta Zoológica Mexicana, Mexico, pp. 153-174.

Huntington HP (2000) Using Traditional Ecological Knowledge in Science: Methods and Applications. Ecological Applications 10:1270-1274.

IUCN (2020) The IUCN Red List of Threatened Species. https://www.iucnredlist.org

Jensen JB, Camp CD (2003) Human exploitation of amphibians: Direct and indirect impacts. Amphibian Conservation 199-213.

Kahn TR, La Marca E, Lötters S, Brown J., Twomey E, Amézquita A (2015) Aposematic Poison Frogs (Dendrobatidae) of the Andean Countries: Bolivia, Colombia, Ecuador, Perú and Venezuela. 
Vergara-Rios et al. 2021. Local community knowledge and perceptions in the Colombian Caribbean towards Amphibians in urban and rural settings: tools for biological conservation

Ethnobio Conserv 10:24

Conservation International Tropical Field Guide Series, Conservation International, Arlington, Virginia, U.S.A.

Kellert SR, Berry JK (1987) Attitudes, Knowledge, and Behaviours toward Wildlife as Affected by Gender. Wildlife Society Bulletin 15:363-371.

Kimmerer RW (2002) Weaving traditional ecological knowledge into biological education: A call to action. BioScience 52:432-438.

De La Ossa-Lacayo A, De La Ossa J (2012) Utilización de fauna silvestre en el área rural de caimito, sucre, colombia. Revista Colombiana de Ciencia Animal - RECIA 4:46.

Legast A (1987) El animal en el mundo mítico Tairona. Publicación de la Fundación de Investigaciones Arqueológicas Nacionales 144-145.

Lindemann-matthies P (2002) The Influence of an Educational Program on Children's Perception of Biodiversity. The Journal of Environmental Education 33:22-31.

Luiz W, Vieira S (2014) Caatinga Ethnoherpetology: Relationships between herpeto- fauna and people in a semiarid region of northeastern Brazil. Amphibian and Reptile Conservation 8:2432 .

Lyra-Neves RM, Santos EM, Medeiros PM, Alves RRN, Albuquerque UP (2015) Etnozoologia no Brasil: Análise de riscos metodológicos nos trabalhos publicados. Brazilian Journal of Biology 75:184-191.

Matas A (2018) Diseño del formato de escalas tipo Likert: Un estado de la cuestión. Revista Electronica de Investigacion Educativa 20:38-47.

Merleau-Ponty M (1985) Fenomenología de la percepción. Planeta-De Agostini, S.A.

Ministerio de ambiente y desarrollo Sostenible (2021) Programa Nacional para la Conservación de los Anfibios en Colombia. Plan de Acción 2020-2030. Bogota.

Miralles A, Raymond M, Lecointre G (2019) Empathy and compassion toward other species decrease with evolutionary divergence time. Scientific Reports 9:1-8.

Montes-Correa A, Saboyá-Acosta L, Vergara-Ríos D, Ávila-Silva Y, Jimenez-Bolaños J, Renjifo JM (2015) Herpetofauna del campus de la Universidad del Magdalena, Santa Marta, Colombia. Revista Biodiversidad Neotropical 5:54.

Mueses-Cisneros JJ, Ballen GA (2007) Un nuevo caso de alerta sobre posible amenaza a una fauna nativa de Anfibios en Colombia: Primer reporte de la Rana Toro (Lithobates catesbeianus). Revista de la Academia Colombiana de Ciencias Exactas, Físicas y Naturales 31:165-166.

Nates-Jimenez J, Campos C, Lindemann-Matthies P (2010) Students' perception of plant and animal species: A case study from rural Argentina. Applied Environmental Education and Communication 9:131-141.

Nates-Jimenez J, Lindemann-Matthies P (2015a) Public knowledge and perception of toads and frogs in three areas of subtropical southeast China. Society and Animals 23:166-192.

Nates-Jimenez J, Lindemann-Matthies P (2015b) Public Knowledge of, and Attitudes to, Frogs in Colombia. Anthrozoos: A Multidisciplinary Journal of The Interactions of People $\&$ Animals 28:319-332.

Nishida AK, Nordi N (2006) Mollusc Gathering in Northeast Brazil: An Ethnoecological Approach. Human Ecology 34:133-145.

Noriega JA, Zapata-Prisco C, García H, Hernández E, Hernández J, Martínez R, Santos-Santos JH, PabloCea JD, Calatayud J (2020) Does ecotourism impact biodiversity? An assessment using dung beetles (Coleoptera: Scarabaeinae) as bioindicators in a tropical dry forest natural park. Ecological Indicators 117:106580.

Osorno M, Jaramillo M, Atuesta N, Barona A, Roncancio N (2014) La Despensa del Tiquié: Diagnóstico y manejo comunitario de La fauna de consumo en La Guayana colombiana, Bogotá. Instituto Amazónico de Investigaciones Científicas "SINCHI."

Pavol P, Fančovičová J (2012) Tolerance of amphibians in Slovakian people: A comparison of pond owners and non-owners. Anthrozoos $25: 277-288$.

Peltzer PM, Lajmanovich RC, Attademo AM, Cejas W (2005) Diversidad y conservación de anuros en ecosistemas agrícolas de Argentina: implicancias en el control biológico de plagas. Miscelánea 14:399-416.

Penguilly-Macias MA, Moreno-Fuentes Á, Goyenechea-Mayer I, Espinosa-Pineda. G (2010) Percepción acerca de las lagartijas consideradas nocivas por algunos otomíes, nahuas, tepehuas y mestizos en el estado de Hidalgo, México. Sistemas biocognitivos tradicionales, paradigmas en la conservación biológica y el fortalecimiento cultural 99-104. 
Riós-Orjuela JC, Falcón-Espitia N, Arias-Escobar A, Espejo-Uribe MJ, Chamorro-Vargas CT (2020) Knowledge and interactions of the local community with the herpetofauna in the forest reserve of Quininí (Tibacuy-Cundinamarca, Colombia). Journal of Ethnobiology and Ethnomedicine 16:1-11.

Roach NS, Urbina-Cardona N, Lacher TE (2020) Land cover drives amphibian diversity across steep elevational gradients in an isolated neotropical mountain range: Implications for community conservation. Global Ecology and Conservation 22:e00968.

Rudd MA (2011) Scientists' Opinions on the Global Status and Management of Biological Diversity. Conservation Biology 25:1165-1175.

Schmidt O (1857) Diagnosen neuer Frösche des zoologischen Cabinets zu Krakau. Akad. Wiss. Wien, Phys. Math. Naturwiss. 24.

Schneider JG (1799) Historia Amphibiorum Naturalis et Literarariae. Fasciculus Primus. Continens Ranas, Calamitas, Bufones, Salamandras et Hydros in Genera et Species Descriptos Notisque suis Distinctos. Jena: Friederici Frommanni.

Selinske MJ, Garrard GE, Gregg EA, Kusmanoff AM, Kidd LR, Cullen MT, Cooper M, Geary WL, Hatty MA, Hames F, Kneebone S, McLeod EM, Ritchie EG, Squires ZE, Thomas J, Willcock MAW, Blair S, Bekessy SA (2020) Identifying and prioritizing human behaviors that benefit biodiversity. Conservation Science and Practice.

Shrestha B, Shah KB (2017) Mountain Survey of Amphibians and Reptiles and their Conservation Status in Manaslu Conservation Area, Gorkha District, Western Nepal. Conservation Science 5:13-18.

Tarrant J, Kruger D, Preez LHD (2016) Do Public Attitudes Affect Conservation Effort Using a Questionnaire-Based Survey to Assess Perceptions, Beliefs and Superstitions Associated with Frogs in South Africa. African Zoology 51:13-20.

Teixeira JVDS, Dos Santos JS, Guanaes DHA, da Rocha WD, Schiavetti A (2020) Uses of wild vertebrates in traditional medicine by farmers in the region surrounding the serra do conduru state park (Bahia, Brazil). Biota Neotropica 20:1-15.
Tomažič I (2011) Reported experiences enhance favourable attitudes toward toads. Eurasia Journal of Mathematics, Science and Technology Education 7:253-262.

Tomažic I, Šorgo A (2017) Factors affecting students' attitudes toward toads. Eurasia Journal of Mathematics, Science and Technology Education 13:2505-2528.

Torres MNY, Medina N (2014) Representaciones en estudiantes de básica primaria acerca de especies carismáticas y no carismáticas en instituciones educativas rurales y urbanas. Biografía. Escritos sobre la Biología y su Enseñanza $7: 21-32$.

Tyler MJ, Wassersug R, Smith B (2007) How frogs and humans interact: Influences beyond habitat destruction, epidemics and global warming. Applied Herpetology 4:1-18.

Valencia-Aguilar A, Cortés-Gómez AM, RuizAgudelo CA (2013) Ecosystem services provided by amphibians and reptiles in Neotropical ecosystems. International Journal of Biodiversity Science, Ecosystem Services and Management 9:257-272.

Vallejo JR, González JA (2015) Amphibians in Spanish popular medicine and the pharmacopoeia of Pliny and Dioscorides. Historia, Ciencias, Saude - Manguinhos 22:1283-1319.

Wiegmann AF (1833) Herpetologischen Beyträge. I. Ueber die mexicanischen Kröten nebst bemerkungen über ihren verwandte Arten anderer Weltgegenden. Isis von Oken 26:651-662.

Xie F, Lau MWN, Stuart SN, Chanson JS, Cox NA, Fischman DL (2007) Conservation needs of amphibians in China: A review. Science in China, Series C: Life Sciences 50:265-276.

Zippel K, Johnson K, Gagliardo R, Gibson R, McFadden M, Browne R, Martinez C, Townsend E (2011) The amphibian Ark: A global community for ex situ conservation of amphibians. Herpetological Conservation and Biology 6:340-352.

Received: 01 June 2020

Accepted: 29 July 2020

Published: 10 May 2021 
Add File 1. PERMANOVA summary tables reporting the contribution of locality, gender, age range, and educational level to the variation of knowledge and perception of amphibians of the people interviewed in urban and rural locations in the Caribbean region of Colombia. Significant sources of variation are highlighted in bold at $\mathrm{P}($ perm $)$ column.

\begin{tabular}{|c|c|c|c|c|c|c|c|c|c|c|}
\hline \multirow[t]{2}{*}{ Response variable } & \multirow[t]{2}{*}{ Source } & \multirow[t]{2}{*}{ df } & \multirow[t]{2}{*}{ SS } & \multirow[t]{2}{*}{ MS } & \multirow[t]{2}{*}{ Pseudo-F } & \multirow[t]{2}{*}{$\mathrm{P}($ perm $)$} & \multirow[t]{2}{*}{ Unique perms } & \multicolumn{2}{|c|}{$\begin{array}{c}\text { Estimates of component } \\
\text { of variation }\end{array}$} & : \\
\hline & & & & & & & & Estimate & Sq.root & \\
\hline \multirow{16}{*}{$\begin{array}{l}\text { KNOWLEDGE: Composition of } \\
\text { taxonomic groups }\end{array}$} & Locality (Lo) & 1 & 6845 & 6845 & 4.94 & 0.0001 & 9953 & 29803 & 5.4592 & \\
\hline & Gender (Ge) & 1 & 536.56 & 536.56 & 0.60654 & 0.6117 & 9951 & 1.7446 & -1.3208 & 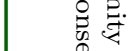 \\
\hline & Age range (AR) & 3 & 8637.7 & 2879.2 & 3.2547 & 0.0019 & 9947 & 26417 & 5.1397 & $\bar{s}$ \\
\hline & Educational level (EL) & 5 & 7643.9 & 1528.8 & 1.7282 & 0.0673 & 9922 & 19382 & 4.4025 & \\
\hline & LoxGe & 1 & 2173.1 & 2173.1 & 2.4565 & 0.0327 & 9954 & 13035 & 3.6104 & \\
\hline & LoxAR & 3 & 2836.3 & 945.43 & 1.0687 & 0.3942 & 9950 & 2.8992 & 1.7027 & \\
\hline & LoxEL & 3 & 901.65 & 300.55 & 0.33975 & 0.9163 & 9940 & 63.76 & -7985 & \\
\hline & GexAR & 3 & 2850.3 & 950.1 & 1074 & 0.3651 & 9940 & 1.8496 & 1.36 & 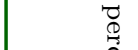 \\
\hline & GexEL & 4 & 4121.9 & 1030.5 & 1.1649 & 0.3082 & 9933 & 7.4541 & 2.7302 & 8 \\
\hline & RAxEL & 8 & $6.12 \mathrm{E}+03$ & 765.1 & 0.86488 & 0.5915 & 9915 & 19413 & -4.4061 & \\
\hline & LoxGexRA & 2 & $1.62 \mathrm{E}+03$ & 810.03 & 0.91568 & 0.4776 & 9953 & 6.5117 & -2.5518 & \\
\hline & LoxGexEL & 2 & 3624.3 & 1812.2 & 2.0485 & 0.0778 & 9947 & 192.01 & 13857 & \\
\hline & LoxARxEL & 2 & 498.15 & 249.07 & 0.28156 & 0.8985 & 9942 & 167.6 & -12946 & \\
\hline & GexARxEL & 5 & 2961.6 & 592.31 & 0.66956 & 0.7508 & 9934 & 94819 & -9.7375 & \\
\hline & Res & 356 & $3.15 \mathrm{E}+05$ & 884.63 & & & & 884.63 & 29743 & \\
\hline & Total & 399 & $3.66 \mathrm{E}+05$ & & & & & 1531.3282 & & \\
\hline \multirow{13}{*}{$\begin{array}{l}\text { KNOWLEDGE: Number of known } \\
\text { taxonomic groups }\end{array}$} & Locality (Lo) & 1 & 1670.9 & 1670.9 & 1554 & 0.0001 & 6170 & 7.3917 & 2.7188 & 2 \\
\hline & Gender (Ge) & 1 & 38.31 & 38.31 & 0.19383 & 0.7576 & 9943 & -7.6547 & -2.7667 & \\
\hline & Age range (AR) & 2 & 29183 & 14591 & 0.073828 & 0.9656 & 9937 & -20876 & -4569 & \\
\hline & Educational level (EL) & 4 & 254.33 & 63582 & 0.3217 & 0.7199 & 9910 & -20.16 & -4.49 & \\
\hline & LoxGe & 1 & 33364 & 33364 & 0.16881 & 0.7152 & 9906 & -17863 & -4.2264 & \\
\hline & LoxAR & 2 & 121.71 & 60853 & 0.30789 & 0.6971 & 9935 & -21577 & -4.6451 & $=$ \\
\hline & LoxEL & 3 & 358.92 & 119.64 & 0.60533 & 0.0426 & 9935 & -17611 & -4.1965 & 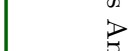 \\
\hline & GexAR & 3 & 371.9 & 123.97 & 0.62723 & 0.4372 & 9928 & -13951 & -3.7351 & $=$ \\
\hline & GexEL & 4 & 750.86 & 187.71 & 0.94977 & 0.2983 & 9920 & -1.7544 & -1.3245 & \\
\hline & RAxEL & 8 & 1137.6 & 142.2 & 0.71948 & 0.4312 & 9927 & -12032 & -3.4688 & हृ \\
\hline & LoxGexRA & 2 & 33288 & 16644 & 0.084213 & 0.9357 & 9915 & -55.08 & -7.4216 & $E$ \\
\hline & LoxGexEL & 2 & 235.05 & 117.52 & 0.59463 & 0.3661 & 9923 & -27943 & -5.2861 & \\
\hline & LoxARxEL & 2 & 45282 & 22641 & 0.11456 & 0.8943 & 9924 & -65246 & -8.0775 & \\
\hline
\end{tabular}




\begin{tabular}{|c|c|c|c|c|c|c|c|c|}
\hline GexARxEL & 5 & 416.16 & 83233 & 0.42113 & 0.7124 & 9938 & -37112 & -6.0919 \\
\hline Res & 356 & 70361 & 197.64 & & & & 197.64 & 14059 \\
\hline Total & 399 & 78316 & & & & & & \\
\hline Locality (Lo) & 1 & 48661 & 48661 & 2983 & 0.0001 & 9965 & 235.96 & 15361 \\
\hline Gender (Ge) & 1 & 132.94 & 132.94 & 0.094865 & 0.9288 & 9958 & -60935 & -7.8061 \\
\hline Age range (AR) & 2 & 3345 & 1672.5 & 1.1935 & 0.3041 & 9942 & 30.93 & 5.5615 \\
\hline Educational level (EL) & 4 & 7698.2 & 1924.5 & 1.3734 & 0.1546 & 9912 & 78683 & 8.8704 \\
\hline LoxGe & 1 & 566.47 & 566.47 & 0.40425 & 0.7547 & 9957 & -90775 & -9.5276 \\
\hline LoxAR & 2 & 791.04 & 395.52 & 0.28225 & 0.0094 & 9946 & -158.65 & -12596 \\
\hline LoxEL & 3 & 1774.7 & 591.57 & 0.42216 & 0.0092 & 9935 & -182.81 & -13521 \\
\hline GexAR & 3 & 2691.5 & 897.16 & 0.64023 & 0.7777 & 9933 & -95462 & -9.7705 \\
\hline GexEL & 4 & 5026 & 1256.5 & 0.89667 & 0.5695 & 9930 & -25588 & -5.0585 \\
\hline RAxEL & 8 & 5322.3 & 665.28 & 0.47476 & 0.9858 & 9906 & -159.74 & -12639 \\
\hline LoxGexRA & 2 & 3806.1 & 1903.1 & 1.3581 & 0.2356 & 9946 & 152.69 & 12357 \\
\hline LoxGexEL & 2 & 5068.6 & 2534.3 & 1.8085 & 0.0857 & 9928 & 395.16 & 19879 \\
\hline LoxARxEL & 2 & 980.28 & 490.14 & 0.34977 & 904 & 9942 & -339.71 & -18431 \\
\hline GexARxEL & 5 & 4522.1 & 904.41 & 0.64541 & 0.8421 & 9895 & -161.18 & -12696 \\
\hline Res & 356 & $4.99 \mathrm{E}+05$ & 1401.3 & & & & 1401.3 & 37434 \\
\hline Total & 399 & $6.34 \mathrm{E}+05$ & & & & & & \\
\hline Locality (Lo) & 1 & 3220.5 & 3220.5 & 3017 & 0.0013 & 9068 & 14626 & 3.8244 \\
\hline Gender (Ge) & 1 & 1.8187 & 1.8187 & 0.0062423 & 0.9814 & 9925 & -13.91 & -3.7296 \\
\hline Age range (AR) & 2 & 598.01 & 299 & 1.0262 & 0.3634 & 9958 & 872 & 0.93381 \\
\hline Educational level (EL) & 4 & 2352.6 & 588.14 & 2.0186 & 0.0846 & 9939 & 44629 & 6.6805 \\
\hline LoxGe & 1 & 326 & 326 & 1.1189 & 0.0289 & 9921 & 3.7668 & 1.9408 \\
\hline LoxAR & 2 & 51681 & 25.84 & 0.088689 & 0.0094 & 9953 & -41882 & -6.4716 \\
\hline LoxEL & 3 & 322.61 & 107.54 & 0.36908 & 0.7975 & 9962 & -41501 & -6.4421 \\
\hline GexAR & 3 & 132.07 & 44023 & 0.1511 & 0.9403 & 9956 & -46835 & -6.8436 \\
\hline GexEL & 4 & 1351.8 & 337.94 & 1.1599 & 0.3286 & 9955 & 8.2314 & 2869 \\
\hline RAxEL & 8 & 1182.3 & 147.79 & 0.50725 & 0.8636 & 9932 & -31158 & -5.5819 \\
\hline LoxGexRA & 2 & 13422 & 6711 & 0.023033 & 0.9926 & 9949 & -86621 & -9307 \\
\hline LoxGexEL & 2 & 1370.7 & 685.33 & 2.3522 & 0.0954 & 9952 & 137.41 & 11722 \\
\hline LoxARxEL & 2 & 112.08 & 56038 & 0.19233 & 0.8511 & 9959 & -87734 & -9.3667 \\
\hline GexARxEL & 5 & 1523 & 304.6 & 1.0455 & 0.3987 & 9955 & 4296 & 2.0727 \\
\hline Res & 356 & $1.04 \mathrm{E}+05$ & 291.36 & & & & 291.36 & 17069 \\
\hline Total & 399 & $1.21 \mathrm{E}+05$ & & & & & & \\
\hline Locality (Lo) & 1 & 110.7 & 110.7 & 2.8634 & 0.0891 & 4410 & 0.36022 & 0.60019 \\
\hline Gender (Ge) & 1 & 32956 & 32956 & 0.90412 & 0.3137 & 9916 & -0.16791 & -0.40977 \\
\hline Age range (AR) & 2 & 20098 & 10049 & 0.27568 & 0.7245 & 9958 & -3011 & -1.7352 \\
\hline
\end{tabular}




Educational level (EL)
LoxGe
LoxAR
LoxEL
GexAR
GexEL
RAxEL
LoxGexRA
LoxGexEL
LoxARxEL
GexARxEL
Res
Total
Locality (Lo)
Gender (Ge)
Age range (AR)
Educational level (EL)
LoxGe
LoxAR
LoxEL
GexAR
GexEL
RAxEL
LoxGexRA
LoxGexEL
LoxARxEL
GexARxEL
Res
Total
Locality (Lo)
Gender (Ge)
Age range (AR)
Educational level (EL)
LoxGe
LoxAR
LoxEL
GexAR
GexEL
RAxEL
LoxGexRA

\begin{tabular}{|c|c|c|c|c|c|c|}
\hline 28623 & 7.1558 & 0.19631 & 0.9051 & 9948 & -4.4054 & -2.0989 \\
\hline 32826 & 32826 & 0.90054 & 0.2965 & 9903 & -0.39422 & -0.62787 \\
\hline 87.36 & 43.68 & 1.1983 & 0.0253 & 9944 & 1.1402 & 1.0678 \\
\hline 39324 & 13108 & 0.3596 & 0.7081 & 9943 & -5.2702 & -2.2957 \\
\hline 92.36 & 30787 & 0.8446 & 0.4017 & 9949 & -1.0726 & -1.0357 \\
\hline 121.97 & 30493 & 0.83654 & 0.4328 & 9930 & -1.0529 & -1.0261 \\
\hline 232.4 & 29.05 & 0.79696 & 0.4884 & 9942 & -1.6062 & -1.2674 \\
\hline 101.1 & 50.55 & 1.3868 & 0.2125 & 9941 & 4.2903 & 2.0713 \\
\hline 11484 & 5.7418 & 0.15752 & 816 & 9947 & -10711 & -3.2727 \\
\hline 43113 & 21556 & 0.59138 & 0.4943 & 9941 & -5.5533 & -2.3565 \\
\hline 201.22 & 40244 & 1104 & 0.3121 & 9942 & 1.2301 & 1.1091 \\
\hline 12977 & 36451 & & & & 36451 & 6.0375 \\
\hline \multicolumn{7}{|l|}{15498} \\
\hline 1459.6 & 1459.6 & 3537 & 0.0001 & 9961 & 6.7956 & 2.6068 \\
\hline 61403 & 61403 & 0.65112 & 0.5986 & 9954 & -1.5807 & -1.2573 \\
\hline 270.01 & 135 & 1.4316 & 209 & 9947 & 4.6416 & 2.1544 \\
\hline 603.9 & 150.98 & 1.6009 & 0.0919 & 9925 & 8.5222 & 2.9193 \\
\hline 19449 & 19449 & 0.20623 & 0.8504 & 9954 & -8.1394 & -2853 \\
\hline 188.19 & 94096 & 0.99778 & 0.0436 & 9953 & -0.032972 & -0.18158 \\
\hline 283.6 & 94535 & 1.0024 & 0.0444 & 9933 & 0.051875 & 0.22776 \\
\hline 147.31 & 49103 & 0.52068 & 0.8371 & 9939 & -8.5597 & -2.9257 \\
\hline 140.37 & 35093 & 0.37212 & 0.9496 & 9935 & -10464 & -3.2348 \\
\hline 711.93 & 88991 & 0.94366 & 0.5404 & 9914 & -1.1532 & -1.0739 \\
\hline 120.55 & 60274 & 0.63914 & 692 & 9950 & -10356 & -3.2181 \\
\hline 286.51 & 143.26 & 1.5191 & 0.1787 & 9938 & 17073 & 4.1319 \\
\hline 182.67 & 91336 & 0.96852 & 0.4539 & 9941 & -1.1069 & -1.0521 \\
\hline 442.37 & 88474 & 0.93817 & 0.5221 & 9922 & -1.8916 & -1.3754 \\
\hline 33478 & 94305 & & & & 94305 & 9.7111 \\
\hline \multicolumn{7}{|l|}{42726} \\
\hline 820.58 & 820.58 & 6.26 & 0.002 & 9962 & 3.3358 & 1.8264 \\
\hline 130.21 & 130.21 & 0.95271 & 0.4237 & 9957 & -0.31054 & -0.55726 \\
\hline 871.94 & 435.97 & 3.1899 & 0.0082 & 9956 & 34132 & 5.8423 \\
\hline 826.22 & 206.56 & 1.5113 & 0.1257 & 9930 & 10509 & 3.2418 \\
\hline 352.23 & 352.23 & 2.5772 & 0.0388 & 9959 & 23438 & 4.8413 \\
\hline 569.29 & 284.65 & 2.0827 & 0.0376 & 9951 & 23341 & 4.8312 \\
\hline 762 & 254 & 1.8584 & 0.0376 & 9951 & 26488 & 5.1467 \\
\hline 757.76 & 252.59 & 1.8481 & 0.0706 & 9931 & 21.95 & 4.6851 \\
\hline 974.99 & 243.75 & 1.7834 & 0.0619 & 9940 & 18922 & 4.3499 \\
\hline 1462.9 & 182.87 & 1338 & 0.1472 & 9910 & 10027 & 3.1665 \\
\hline 251.06 & 125.53 & 0.91849 & 0.4891 & 9950 & -3.3901 & -1.8412 \\
\hline
\end{tabular}




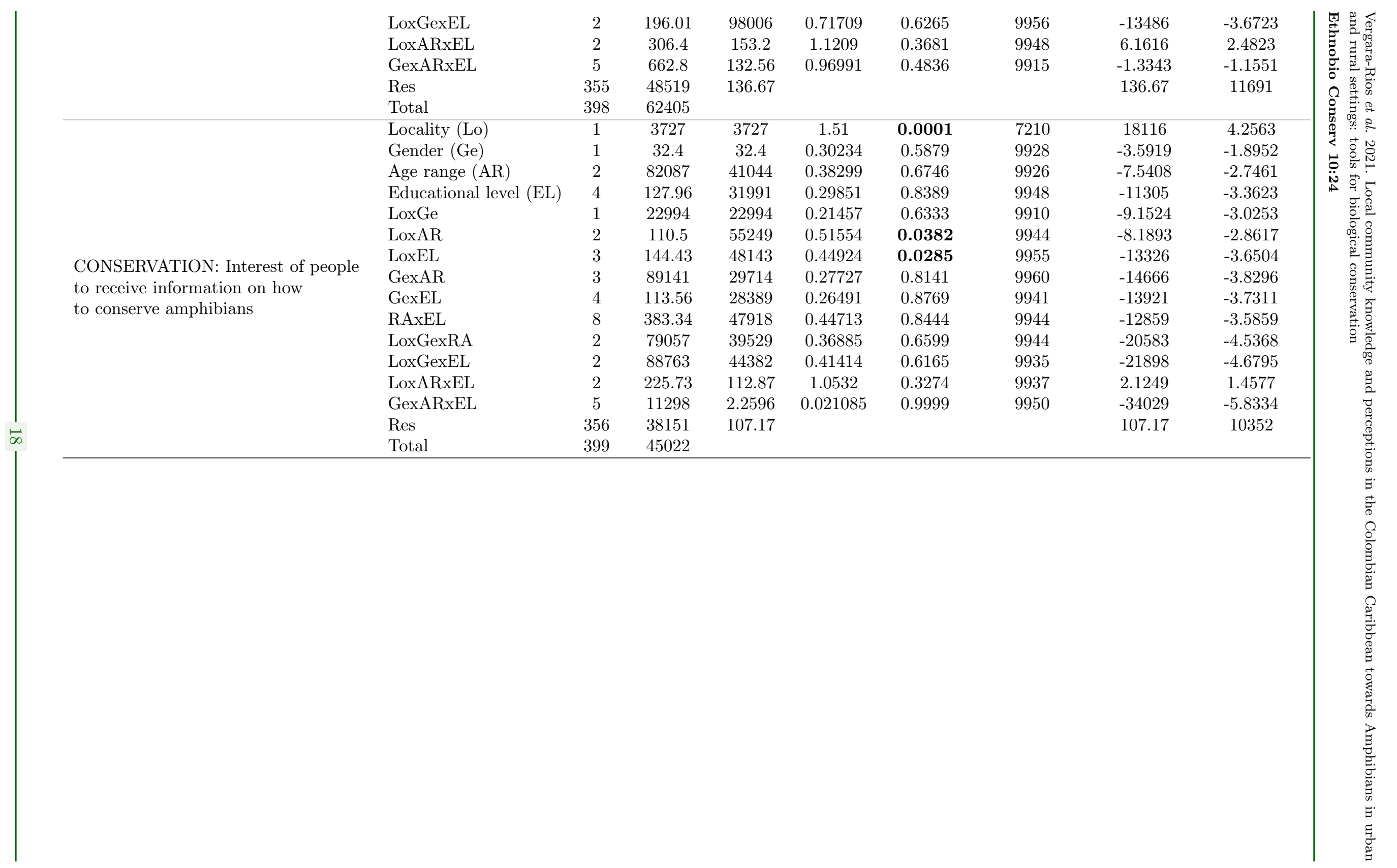


Add File 2. Pearson correlation coefficient between knowledge and perception of amphibians with sociodemographic variables of the people interviewed in urban and rural locations in the Caribbean region of Colombia.

\begin{tabular}{|c|c|c|c|c|c|c|c|c|c|c|c|c|c|c|c|c|}
\hline & 1 & 2 & 3 & 4 & 5 & 6 & 7 & 8 & 9 & 10 & 11 & 12 & 13 & 14 & 15 & 16 \\
\hline \multicolumn{17}{|l|}{ Medicinal use (1) } \\
\hline Use for food (2) & 0.28 & & & & & & & & & & & & & & & \\
\hline Are nice $(3)$ & 0.17 & 0.05 & & & & & & & & & & & & & & \\
\hline Use for pets (4) & 0.05 & 0.17 & 0.03 & & & & & & & & & & & & & \\
\hline Control harmful insects (5) & 0.01 & -0.02 & 0.12 & 0.01 & & & & & & & & & & & & \\
\hline Sing (6) & -0.02 & 0.02 & 0.09 & -0.10 & 0.20 & & & & & & & & & & & \\
\hline Secrete milky substances (7) & -0.13 & -0.08 & -0.13 & 0.02 & 0.10 & 0.13 & & & & & & & & & & \\
\hline Inflate or explode (8) & 0.01 & 0.06 & -0.03 & -0.03 & -0.05 & 0.12 & 0.21 & & & & & & & & & \\
\hline Cause warts (9) & 0.09 & 0.12 & -0.11 & 0.00 & -0.11 & -0.09 & 0.20 & 0.27 & & & & & & & & \\
\hline Carry diseases (10) & -0.04 & 0.10 & -0.23 & 0.07 & -0.13 & -0.08 & 0.07 & 0.12 & 0.34 & & & & & & & \\
\hline Are harmful (11) & -0.09 & -0.04 & -0.39 & 0.10 & -0.09 & -0.16 & 0.06 & 0.13 & 0.21 & 0.24 & & & & & & \\
\hline $\begin{array}{l}\text { Number of known taxonomic } \\
\text { groups (12) }\end{array}$ & 0.10 & 0.03 & -0.03 & 0.12 & -0.07 & -0.06 & -0.03 & -0.11 & 0.00 & 0.00 & 0.03 & & & & & \\
\hline Number of species of anurans (13) & 0.14 & 0.07 & 0.10 & 0.08 & 0.03 & 0.06 & -0.02 & 0.01 & -0.03 & -0.07 & 0.01 & 0.06 & & & & \\
\hline Age (14) & 0.05 & -0.03 & 0.23 & -0.20 & 0.14 & 0.26 & 0.03 & 0.19 & -0.10 & -0.21 & -0.19 & -0.13 & 0.11 & & & \\
\hline Gender (15) & -0.10 & -0.02 & -0.13 & -0.07 & -0.02 & 0.04 & 0.05 & 0.10 & 0.10 & 0.05 & 0.06 & -0.08 & -0.08 & 0.00 & & \\
\hline Locality (16) & -0.17 & -0.24 & -0.10 & -0.03 & 0.15 & 0.20 & 0.18 & 0.16 & 0.00 & 0.03 & 0.01 & -0.22 & -0.18 & 0.07 & -0.02 & \\
\hline Educational level (17) & 0.21 & 0.22 & 0.21 & -0.04 & -0.10 & -0.02 & -0.26 & -0.02 & -0.07 & -0.12 & -0.08 & 0.20 & 0.18 & 0.12 & 0.00 & -0.65 \\
\hline
\end{tabular}


Add File 3. Adjusted models explaining people's interest in receiving information on how to conserve amphibians in urban and rural areas in the Caribbean region of Colombia. Best adjusted model per each locality is highlighted in bold.

\begin{tabular}{lcccl}
\hline \hline & AICc & RSS & Number of variables & Selected variables \\
\hline \hline & 1014.8 & 30691 & 1 & 3 \\
& 1013.1 & 30128 & 2 & $3 ; 4$ \\
Urban locality & 1013.6 & 29895 & 3 & $3 ; 4 ; 7$ \\
& 1014.2 & 29662 & 4 & $3-5 ; 7$ \\
& 1015 & 29473 & 5 & $3-5 ; 7 ; 9$ \\
& 1016.3 & 29352 & 6 & $3-7 ; 9$ \\
& 1037.3 & 29098 & 16 & All \\
& 751.36 & 8625.8 & 1 & 14 \\
& 743.18 & 8190.9 & 2 & $5 ; 14$ \\
& 740.58 & 7999.6 & 3 & $5 ; 12 ; 14$ \\
& 737.98 & 7811.4 & 4 & $5 ; 8 ; 12 ; 14$ \\
& 736.02 & 7652.1 & 5 & $5 ; 8 ; 12 ; 14 ; 16$ \\
& 735.18 & 7537.1 & 6 & $2 ; 5 ; 8 ; 12 ; 14 ; 16$ \\
& 734.84 & 7442.2 & 7 & $2 ; 5 ; 6 ; 8 ; 12 ; 14 ; 16$ \\
& $\mathbf{7 3 4 . 5 6}$ & $\mathbf{7 3 4 9 . 8}$ & $\mathbf{8}$ & $\mathbf{1 ; 2 ; 5 ; 6 ; 8 ; 1 2 ; 1 4 ; 1 6}$ \\
& 747.23 & 7138.4 & 16 & All \\
\hline \hline
\end{tabular}

$1=$ Medicinal use; $2=$ Use for food; $3=$ Are nice; $4=$ Use for pets; $5=$ Control harmful insects; $6=$ Sing; $7=$ Secrete milky substances; $8=$ Inflate or explode; $9=$ Cause warts; $10=$ Carry diseases; $11=$ Are harmful; $12=$ Number of known taxonomic groups; $13=$ Number of species of anurans; $14=$ Age; $15=$ Gender; $16=$ Educational level 
Add File 4. Description of the number of people interviewed by socio-demographic and geographic factors (age, gender, educational level and location)

\begin{tabular}{|c|c|c|c|c|c|c|c|c|}
\hline Locality & Gender & Age range & Educational level & Strongly disagree & Disagree & Neither agree/disagree & Agree & Totally agree \\
\hline \multirow{27}{*}{ RURAL } & \multirow{13}{*}{ Female } & \multirow{2}{*}{ ADOLESCENT } & Primary & 2 & & 10 & 25 & 18 \\
\hline & & & Secondary & & & & & 3 \\
\hline & & \multirow{5}{*}{ ADULTS } & none & & & & & 5 \\
\hline & & & Primary & & & & & 7 \\
\hline & & & Professional & & & & & 1 \\
\hline & & & Secondary & & & & 1 & 6 \\
\hline & & & Technical & & & & 2 & \\
\hline & & \multirow{4}{*}{ YOUNG ADULTS } & Primary & & & & & 1 \\
\hline & & & Professional & & & & & 2 \\
\hline & & & Secondary & & & & & 6 \\
\hline & & & Technical & & & & & 2 \\
\hline & & \multirow{2}{*}{ OLDER ADULTS } & none & & & & & 1 \\
\hline & & & Primary & & & & & 1 \\
\hline & \multirow{14}{*}{ Male } & \multirow{2}{*}{ ADOLESCENT } & Primary & 2 & 3 & 9 & 19 & 28 \\
\hline & & & Secondary & & & & & 6 \\
\hline & & \multirow{5}{*}{ ADULTS } & none & & & & & 5 \\
\hline & & & Primary & & & & & 5 \\
\hline & & & Professional & & & & & 4 \\
\hline & & & Secondary & & & & & 3 \\
\hline & & & Technical & & & & & 1 \\
\hline & & \multirow{5}{*}{ YOUNG ADULTS } & none & & & & & 1 \\
\hline & & & Primary & & & 1 & & 2 \\
\hline & & & Professional & & & & 1 & 3 \\
\hline & & & Secondary & & & & & 5 \\
\hline & & & Technical & & & & & 1 \\
\hline & & \multirow{2}{*}{ OLDER ADULTS } & none & & & & & 2 \\
\hline & & & Primary & & & & & 2 \\
\hline \multirow{9}{*}{ URBAN } & \multirow{9}{*}{ Female } & ADOLESCENT & Secondary & 7 & 2 & 5 & 9 & 19 \\
\hline & & \multirow{6}{*}{ YOUNG ADULTS } & none & & & & & 1 \\
\hline & & & Professional & 3 & 1 & & 2 & 3 \\
\hline & & & Secondary & & & & 1 & \\
\hline & & & Professional & 2 & 3 & 4 & 14 & 8 \\
\hline & & & Secondary & 1 & & & & 1 \\
\hline & & & Technical & 2 & 3 & 1 & 2 & 4 \\
\hline & & \multirow[b]{2}{*}{ ADOLESCENT } & Professional & & & & 1 & \\
\hline & & & Secondary & 4 & 4 & 11 & 9 & 22 \\
\hline
\end{tabular}


Technical

Professional

Technical

Professional

ADULTS

YOUNG ADULTS

Secondary

Technical

OLDER ADULTS Professional

\begin{tabular}{ccc} 
& 1 & \\
& 2 & 1 \\
& 1 & 2 \\
2 & 10 & 10 \\
& 1 & \\
& 1 & 2 \\
\hline
\end{tabular}

